\title{
Comparative Morphological, Microscopical Study of Ocimum Species: Research Article
}

\author{
Shital R Ingole 1*, S. L. Deore ${ }^{2}$ \\ 1.P.R.Pote Patil College of Pharmacy, Amravati, India \\ 2.Department of Pharmacognosy, Government College of Pharmacy, SGBU Amravati, India
}

\begin{abstract}
Now a days, increasing use of herbal products needs to study the medicinal plants by more appropriate study in relation to maintain its quality standards. In this paper, the literature and the published work on comparative Pharmacognostical study of Ocimum species. Aim of present study is to establish comparative standards for different species of Ocimum, to collect and comparatively evaluate morphological microscoscopical characters of different species of Ocimum, to comparatively evaluate micro chemical parameters of different species, to develop comparative standards to differentiate species of Ocimum. The T.S of leaf shows the presence of epidermis, parenchymatous cells, collateral vascular bundle, lateral vein, glandular trichomes which are peltate type and sessile. Powder microscopy of the leaf shows the presence of epidermal peelings and multicellular unbranched trichomes. In present study, the authenticated plants were studied for Pharmacognostical Evaluations including study of Macroscopic Evaluations, Microscopic Evaluations. The macroscopic of leaves and steam of each species was studied by observing the organoleptic characters such as colour, size, texture and surface characteristics.
\end{abstract}

Keywords: Ocimum americanum, Ocimum basilicum, Ocimum kilimandscharicum, Ocimum gratissimum, Ocimum sanctum. 


\section{INTRODUCTION}

Standardization as defined by American Herbal Product association: "Standardization refers to the body of information and control necessary to product material of reasonable consistency. Standardization of drugs means confirmation of its identity and determination of its quality and purity. At present due to advancement in the Morphological knowledge of crude drugs various methods like botanical, chemical and micro chemical to develop literature for comparative study of Ocimum species. Plants have been known to relieve various diseases in Ayurveda. Standardization of herbal medicine is process of prescribing a set of standards or inherent characteristic, constant, definitive, qualitative \&quantities value that carry an assurance of quality, efficacy, safety\& predictability. It is process of developing and agreeing upon chemical standards. The specific standards are workout by experimentation \&observation which would lead to process of observing prescribing set of chrematistics exhibiting by particular herbal medicine.(1)

When the active principles chiefly responsible for the desired therapeutic effect are known, the levels of such constituents may be adjusted by blending different lots of raw material, whether whole herb or extract. The highest aim of standardization is obviously to provide a product of consistent high quality which reliably delivers a health benefit. In the vast majority of cases, however, active principles are either totally unknown or are not well defined. As a consequence, the herbal preparation in its entirety is regarded as the medicine. In most cases, therefore, one has to rely on chemical markers, preferably highly characteristic of the plant and, if even not significantly contributory to its therapeutic effect, at least correlated with it.

\section{Ocimum species}

Throughout the world, there are so many species of Ocimum are available, in the most of the species are used as medicinal plant for the various treatments. So in present thesis is dedicated to comparative study of five local species of Ocimum available in Amravati and Akola i:e in Vidarbha region in Maharashtra in India.

Medicinal properties of Ocimum are known for thousand years to various civilizations of the world. This medicinal herb is considered as a sacred plant by the Hindus in the India subcontinent. Scientific explorations of traditional belief of medicinal properties of Ocimum have got momentum mostly after the middle of the 20th century. (2) Tulsi is a sacred medicinal plant considered as a Holy Hindu Laxmi Goddess. It is member of mint or Labiatae family from India. Medicine is obtained from leaves, seed\& stem. 


\section{Uses:}

cold, influenza, H1N1 (swine flu) hepatitis, bronchitis, stress .cancer, headache, heart disease, malaria, digestive disorder. This is powerful anti-oxidant demonstrated as anti-fungal antibacterial. Act as anti-inflammatory, immunomodulatory, increase metabolism and lowering down stress hormones. This is also a repellant for mosquitos. This has strong healing power in cattarrha matter and phelgm. This also work as supplements to combat Stress by lowering corticosteroid level by active compounds at therapeutic dosages \& standardized for Eugenol, caryophyllene and triterpenoic acid such as ursolic and oleanolic acid .Tulsi has antifertility \&anti sperm role by reducing estrogen in female It has strong immunomodulator and Adoptogen to counter life style diseases in cancer hypertension diabetes and stress.(3)

The complex taxonomy of the genus, Determined by interspecific hybridizations and polyploidy, includes 150 species. Whole plant is used as a source of remedy. In India two forms of Tulsi are more common - dark or Shyama (Krishna) Tulsi and light or Rama Tulsi. The former possesses greater medicinal value and is commonly used for worship. Various other species are also commonly found in India like O. canum, O. basilicum, O. kilimandscharicum, O. ammericanum, $O$. camphora and $O$. micranthum in the past few decades, many of these benefits have been investigated and verified by modern scientific research. Osmium's main Ayurvedic guna (quality) as a healing herb is its ability to enhance the energetic resonance between the body and the environment. "The Elixir of Life", Ocimum has been traditionally employed in hundreds of different formulations for the treatment of a wide disorders including those of the mouth and throat, lungs, heart, blood, liver, kidney, and the digestive, metabolic, reproductive and nervous systems. (2)

\section{EXPERIMENTAL WORK}

\section{Ocimum ammericanum:}

Plant material was purchased from local Gayatrii nursery, Badnera road Amravati. Identification and authentication was made from Dr. Satish N. Malode, H.O.D Botany department, Government Vidarbha Institute of science \& Humanities, Amravati (M.S.)

\section{Ocimum basilicum:}

Plant material was purchased from local Gayatrii nursery, Badnera road Amravati. Identification and authentication was made from Dr. Satish N. Malode, H.O.D Botany department, Government Vidarbha Institute of science \& Humanities, Amravati (M.S.)

\section{Ocimum kilimandscharicum:}


Plant material was purchased from Nagarjun Garden Dr. P.D.K.V. Akola. Identification and authentication was made from Dr. Satish N. Malode, H.O.D Botany department, Government Vidarbha Institute of science \& Humanities, Amravati (M.S.)

\section{Ocimum gratissimum:}

Plant material was purchased from Nagarjun Garden Dr. P.D.K.V. Akola. Identification and authentication was made from Dr. Satish N. Malode, H.O.D Botany department, Government Vidarbha Institute of science \& Humanities, Amravati (M.S.)

\section{Ocimum sanctum:}

Plant material was collected from my home garden. Identification and authentication was made from Dr. Satish N. Malode, H.O.D Botany department, Government Vidarbha Institute of science \& Humanities, Amravati (M.S.)

Herbarium preparation; -

A herbarium is a historical record of documenting of plant information. A herbarium is an institution housing a collection of preserved plants that have been gathered and classified over long period of time. Importance 1) conservation of biodiversity. 2) Provide material for Comparative botanical study.3) It helps to identify variation within the species. 4) Any herbarium is bank of rare and endangered species. 5) Herbarium provide sample for the identification of plant that may be significant in criminal investigation. Steps in herbarium preparation:

$>\quad$ Collection

$>\quad$ Identification of plant specimen

$>\quad$ Pressing and drying plant specimen

$>\quad$ Mounting herbarium specimen $\mathrm{s}$

$>\quad$ Herbarium specimen labels(4)

\section{Pharmacognostical Evaluations}

\section{Macroscopic Evaluations:}

Macroscopy of whole plant was studied by observing the organoleptic characters such as color, odor, size, shape, taste and special features including touch and texture etc. Organoleptic evaluations can be done by means of organs of special sense which includes the above parameters and thereby define some specific characteristics of the material which can be considered as a first step towards establishment of identity .(5)

\section{Microscopic Evaluations:}


Microscopic evaluation is indispensable in the initial identification of herbs as well as identifying small fragment of crud or powdered herbs, and in detection of adulterants. This study helps in identifying characteristics tissue features. Every plant possess a characteristics tissue structure which can be demonstrated through study of tissue arrangement, cell walls and configurations, when properly maintained in stains, reagents and media. Thus it determines the size, shape, and relative structure of different cell (5) Microscopical parameters observed were,

- Arrangement of tissues in a transverse section.

- Type of epidermal cells, stone cells, testa and endosperm.

- Presence and type of crystalline structures e.g. Calcium oxalate, starch etc.

- Presence of oil globules, aleurone grains and trichomes.

All determination was carried out by using Light microscope (Olympus, model no. U-APT, Cx31RTSF). (10x, $40 \mathrm{xs})$

\section{Procedure for taking transverse sections:}

Here, fresh leaves and stems was used for sectioning part of plant. Stems were sectioned vertically holding in finger with the help of sharp razor blade. In case of leaves, potato cubes was used for taking proper sections of the leaves. Using sharp blade transverse section were taken and transferred to watch glass containing water with the help of brush. Thin uniform section was treated with different reagents. (5).

\section{Powder microscopy of whole dried plant:}

The powder of respective plant was used for powder microscopy study (5). Place one or two drop of water, glycerol/ethanol on a glass slide. The tip of needle was moisten with water and dip into the powder. The small quantity of material that adheres to the needle tip was transferred into the drop of fluid on the slide. Stirred thoroughly, and cover glass was applied. Cover glass was press with the help of Handel of the needle. And excess of fluid was removed from the margin of the cover glass with strip of filter paper. Treat a powder sample with following reagents:

\section{Phloroglucinol and hydrochloric acid -}

It establish lignification's in cells and tissues. To the material on slide one or two drops of solution if Phloroglucinol was added mixed, the solvent was allowed to evaporate almost completely. One or two drops of hydrochloric acid were added and the material was covered with cover glass. T. S. was examined immediately: science the colour gradually fades. Heavy lignification's give deep red colour and slight lignification's a pink pale colour. (5) Iodine solution: It was used to conform starch grains content. (5) Sudan red solution: It was used to 
determine the oil globules if present in the section. The structure seen under microscope were studied and captured with the help of camera. (5)

\section{RESULTS AND DISCUSSION}

Total five species of Ocimum i.e. Ocimum sanctum Linn, Ocimum americanum Linn, Ocimum basilicum Linn, Ocimum gratissimum Linn, Ocimum kilimandscharicumguerke were collected from different locations and identified as well as authenticated from Dr. Satish N. Malode, H.O.D Botany department, Government Vidarbha Institute of Science and Humanities, Amravati (M.S.) Authenticated species further evaluated comparatively for their morphological, microscopical, physiochemical, and phytochemical parameters and also evaluated for their antioxidant and antimicrobial activity by in vitro methods.

Macroscopy of leaves and stem as well as powder of whole plant studied in detail. Microscopical examination of leaf $O$. americanum shows isobilateral lamina covered with cuticle; glandular trichomes with multicellular head and multi cellular warty covering trichomes. Mid rib with arc shaped vascular bundle consisting of xylem and phloem. three to four layers of collenchymatous tissue present on upper side of vascular bundle whereas stem part shows cork, vascular bundle containing xylem \& phloem, spongy tissue, collenchymatous cells, pith. Powder microscopy shows reticulate xylem vessel, stone cell, epidermal cell, collenchymas, cork cell.

Ocimum basilicum leaf shows the presence of multicelluler curved trichomes, Upper epidermis, collenchymatous cells, upper palsied cell, vascular bundle containing xylem \& phloem, spongy tissue, lower epidermis, stem section shows unicellular covering trichomes, epidermal cell, collenchymatous cells, vascular bundle containing xylem \& phloem, spongy tissue, pith, spongy parenchyma. Powder microscopy shows presence of medullary rays lamellar collenchymas, Cork cell, Epidermal cell, Fibers, Stone cell. One species contain trichomes on the stem such as Ocimum gratissimum

Ocimum gratissimum showed Single layered epidermis, multicellular covering trichomes and glandular trichomes, collenchymatous cells, Vascular bundle consisting of xylem and phloem, Palisade cells and spongy tissue A transverse section of stem showed Shape of section was rectangular Compressed bark cells followed by single layered epidermis Multicellular covering trichomes and glandular trichomes, Collenchymatous cells, Vascular bundle contains xylem and phloem, Spongy tissue was present at center. Powder microscopy glandular trichomes with multicellular head, Thin walled fiber with pointed end, multicellular covering trichome, 
Diacytic stomata, Wavy walled epidermal cells, Collenchymatous cell with intercellular spaces, Vessels. This species can be identified as highly multicelluler trichome containing species.

Ocimum. kilimandscharicum leaf part shows multicelluler covering trichomes, multicelluler curved trichomes, upper epidermis upper palsied cell, vascular bundle containing xylem \& phloem, Collenchymatous cells, and stem part shows cork, Collenchymatous cells, vascular bundle containing xylem \& phloem, multicellular curved trichomes, pith and powder microscopy shows Storage parenchyma, Reticulate xylem vessel, multi cellular curved trichomes, Stone cell.

Ocimum sanctum leaf microscopy shows Unicellular covering trichomes, Glandular trichomes Upper epidermis, Upper palsied cell, Vascular bundle containing xylem \& phloem, collenchymatous cells, Parenchyma cell, Epidermal cell. Stem shows cork, collenchymatous cells, pith, and medullar rays. Powder microscopy shows, glandular trichomes, fiber multicellular curved trichomes, sclerenchymatous fiber, and stomata cell cork cell bicuspid epidermal cells.

Table 1: Comparative table of morphology of Ocimum species

\begin{tabular}{|c|c|c|c|c|c|}
\hline $\begin{array}{l}\text { Paramet } \\
\text { er }\end{array}$ & $\begin{array}{l}\text { Ocimum } \\
\text { americanum }\end{array}$ & $\begin{array}{l}\text { Ocimum } \\
\text { basilicum }\end{array}$ & $\begin{array}{l}\text { Ocimum } \\
\text { gratissimum }\end{array}$ & $\begin{array}{l}\text { Ocimum } \\
\text { kilimandscharic } \\
\text { um }\end{array}$ & $\begin{array}{l}\text { Ocimum. } \\
\text { sanctum }\end{array}$ \\
\hline Colour & $\begin{array}{l}\text { Green to } \\
\text { yellow green }\end{array}$ & $\begin{array}{lr}\text { Green } & \text { or } \\
\text { some } & \text { time } \\
\text { purple } & \\
\end{array}$ & Light green & Pale green & Green to purple \\
\hline Odour & Aromatic & Faint & Aromatic & Aromatic & Aromatic \\
\hline Taste & $\begin{array}{l}\text { Characteristic } \\
\text { mint like } \\
\text { flavour }\end{array}$ & $\begin{array}{l}\text { Characteristi } \\
\text { c }\end{array}$ & $\begin{array}{l}\text { Oily and sharp, } \\
\text { tingling taste } \\
\text { like cloves, } \\
\text { pungent. }\end{array}$ & $\begin{array}{l}\text { Aromatic } \\
\text { camphor like }\end{array}$ & $\begin{array}{l}\text { Warm \& } \\
\text { pungent, aromatic } \\
\text { and sharp. }\end{array}$ \\
\hline Height & $30-60 \mathrm{~cm}$ & $60-80 \mathrm{~cm}$ & 1 to $1.5 \mathrm{~m}$ & 15 to $30 \mathrm{~cm}$ & $20-60 \mathrm{~cm}$ \\
\hline Herb & $\begin{array}{l}\text { Branched } \\
\text { herb, } \\
\text { branches are } \\
\text { sub- } \\
\text { quadrangular } \\
\text { striate ; light } \\
\text { puff colored } \\
\text { stem }\end{array}$ & $\begin{array}{l}\text { Erect, } \\
\text { strongly } \\
\text { aromatic, } \\
\text { nearly } \\
\text { glabrous } \\
\text { branching } \\
\text { herb, covered } \\
\text { with soft } \\
\text { spreading } \\
\text { hairs }\end{array}$ & $\begin{array}{ll}\text { Stem } & \text { and } \\
\text { branches } & \text { are } \\
\text { green } & \end{array}$ & $\begin{array}{l}\text { Perennial } \\
\text { aromatic } \\
\text { evergreen under } \\
\text { shrub Stems are } \\
\text { brownish green, }\end{array}$ & $\begin{array}{l}\text { Much branched, } \\
\text { stems and } \\
\text { branches usually } \\
\text { purplish, sub- } \\
\text { quadrangular, } \\
\text { woody, Covered } \\
\text { with soft } \\
\text { spreading hairs }\end{array}$ \\
\hline
\end{tabular}




\begin{tabular}{|c|c|c|c|c|c|}
\hline Plant & & & & & \\
\hline Leaves & & & & & \\
\hline Venation & Pinnate & Pinnate & Pinnate & Pinnate & Pinnate \\
\hline Margin & Serrate & Lobed & Entire & Serrate & Entire \\
\hline Fruit & ${ }_{i}^{1}$ & : & 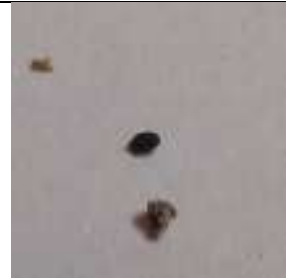 & & 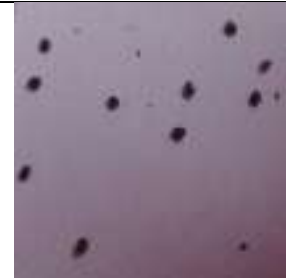 \\
\hline Shape & $\begin{array}{l}\text { Small; nut } \\
\text { lets are pitted, }\end{array}$ & $\begin{array}{l}\text { Ellipsoid nut } \\
\text { lets, } \\
\text { And pitted. }\end{array}$ & $\begin{array}{l}\text { Elongated, } \\
\text { round at one } \\
\text { end and } \\
\text { flattened at the } \\
\text { other }\end{array}$ & $\begin{array}{l}\text { Ovoid, smooth } \\
\text { or minutely } \\
\text { tuberculate, }\end{array}$ & Caeruleus \\
\hline Colour & Black & Black & Black & Black & Brownish Black \\
\hline
\end{tabular}

Microscopical evaluations

Figure 1: Microscopy leaf of $O$. americanum where 1-Multicellular covering trichomes, 2Glandular trichomes, 3- Upper epidermis, 4- Upper palisade cell, 5-Vascular bundle containing xylem \& phloem, 6- Collenchymatous cells, 7- Oil globules, 8-Spongy tissue, 9- 
Ingole et al.,

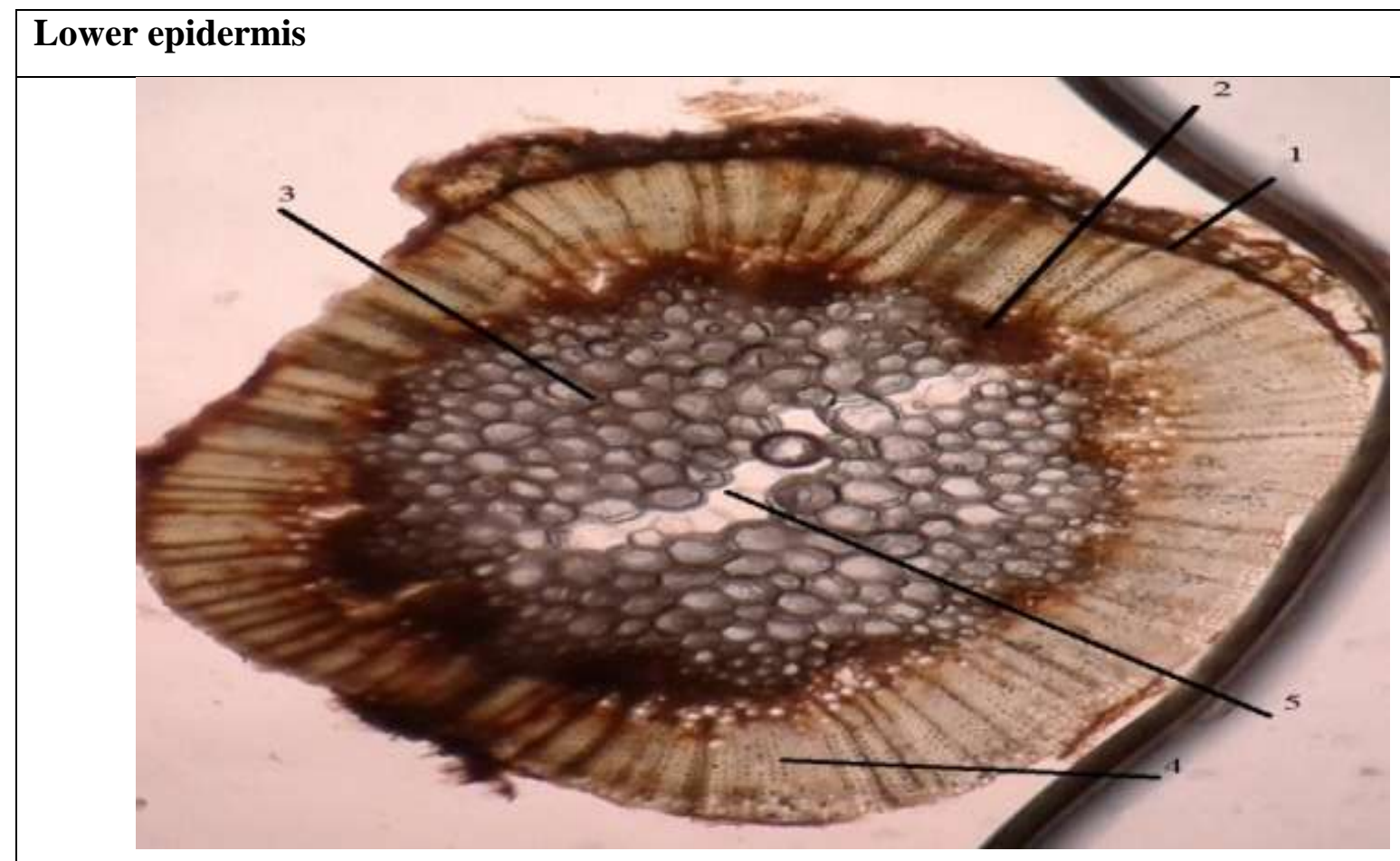

Figure 2: Microscopy of stem of O. americanum where 1-Cork, 2- Vascular bundle containing xylem \& phloem, 3-Spongy tissue, 4-Collenchymatous cells, 5-pith.

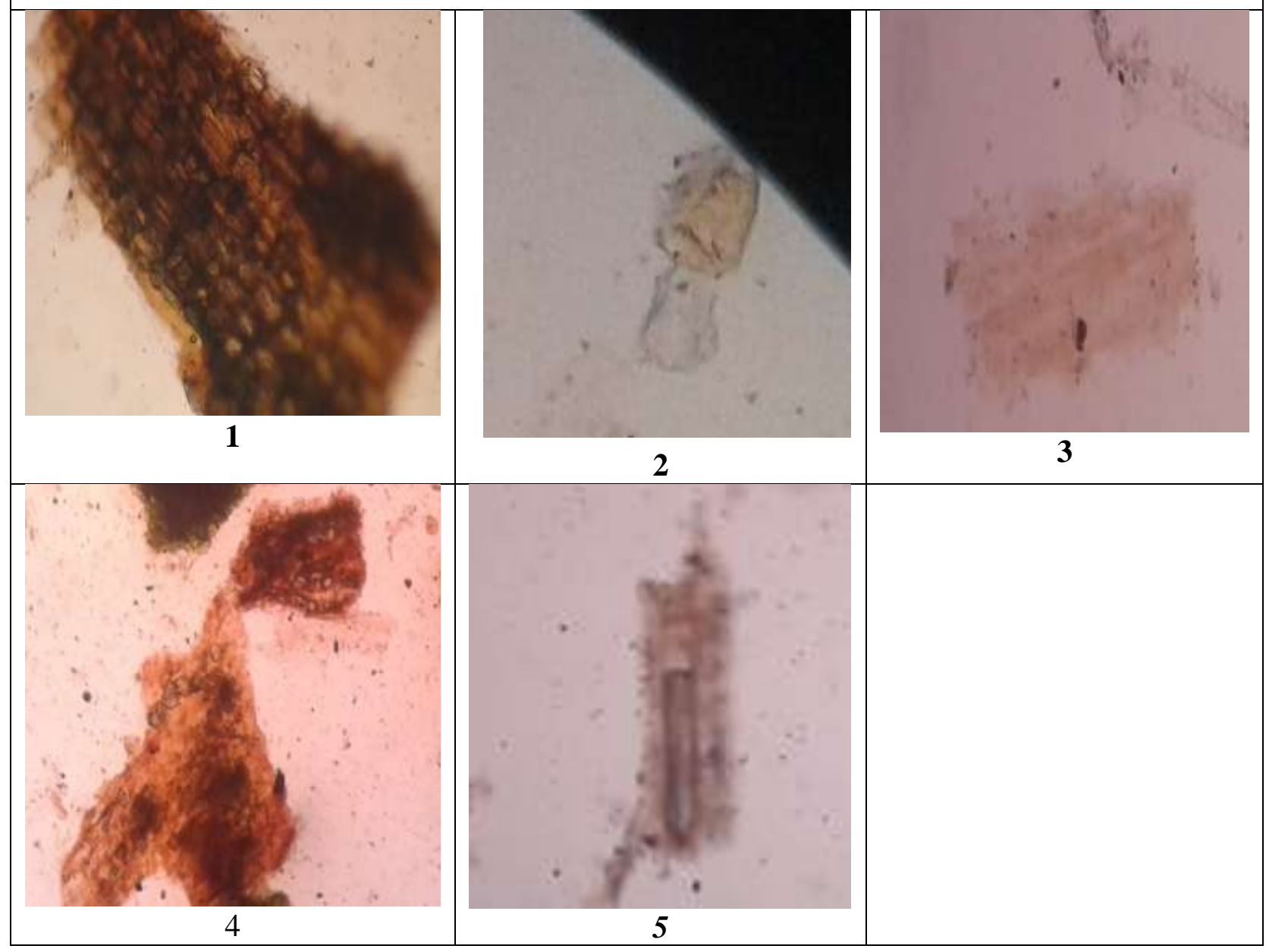


Figure 3: Powder microscopy Ocimum americanum where 1-Cork cell, 2-Stone cell, 3epidermal cell, 4-Collenchymas, 5-Reticulate Xylem vessel

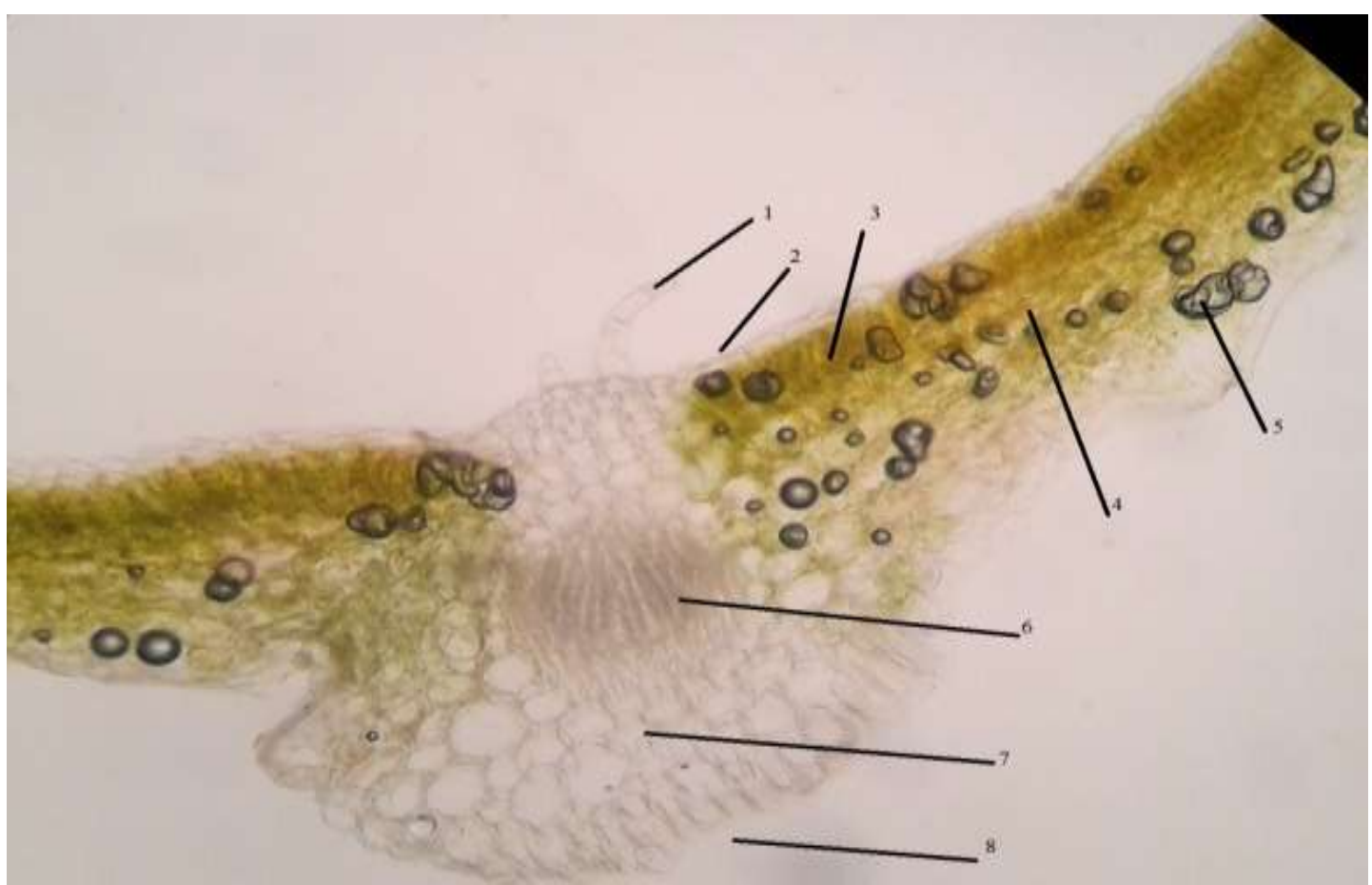

Figure 4: Microscopy leaf of $O$. basilicum where 1-Multicellule curved trichomes, 2- Upper epidermis, 3-Collenchymatous cells, 4- Upper palsied cell, 5-oil globules, 6- Vascular bundle containing xylem \& phloem, 7- Spongy tissue 8- Lower epidermis

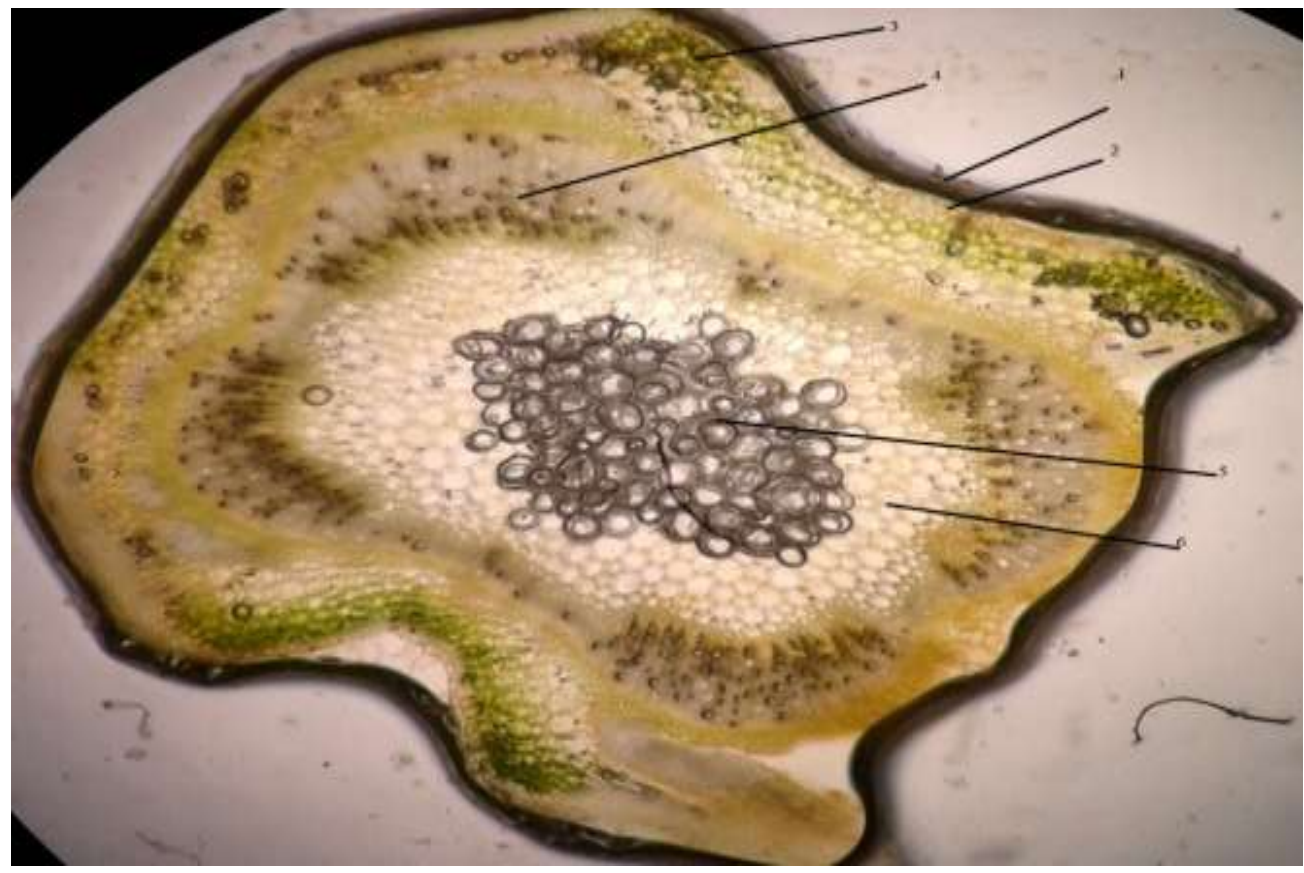

Figure 5:Microscopy stem of $O$. basilicum1-Unicellular covering trichome, 2- Epidermal cell, 3- Collenchymatous cells, 4-Vascular bundle containing xylem \& phloem, 4-Spongy 
tissue, 5-Pith, 6- spongy parenchyma
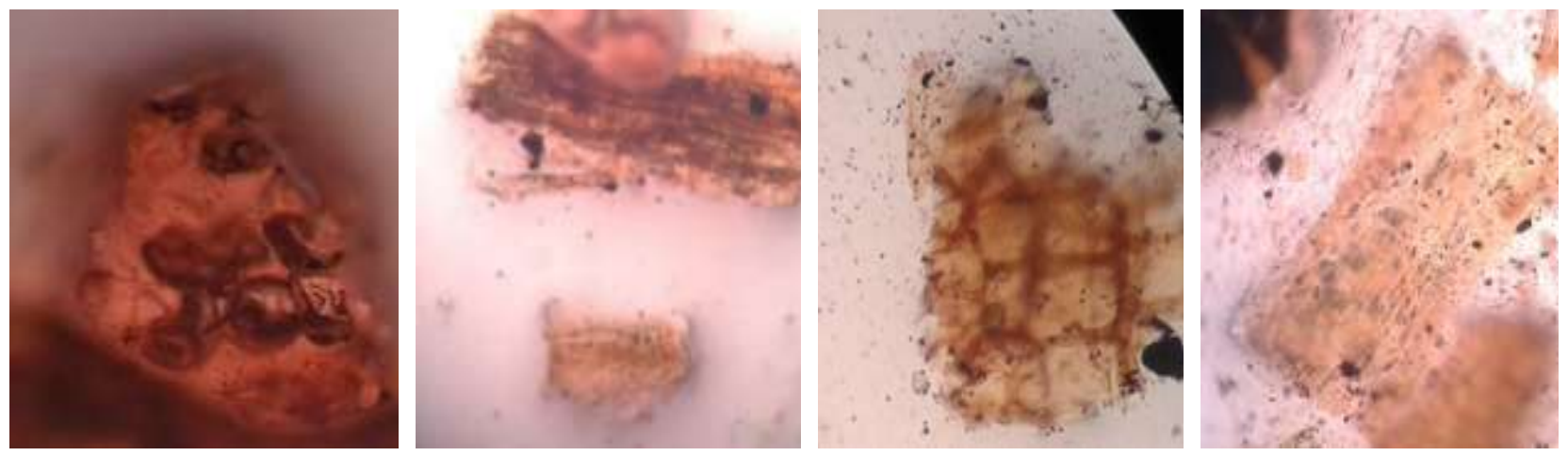

7
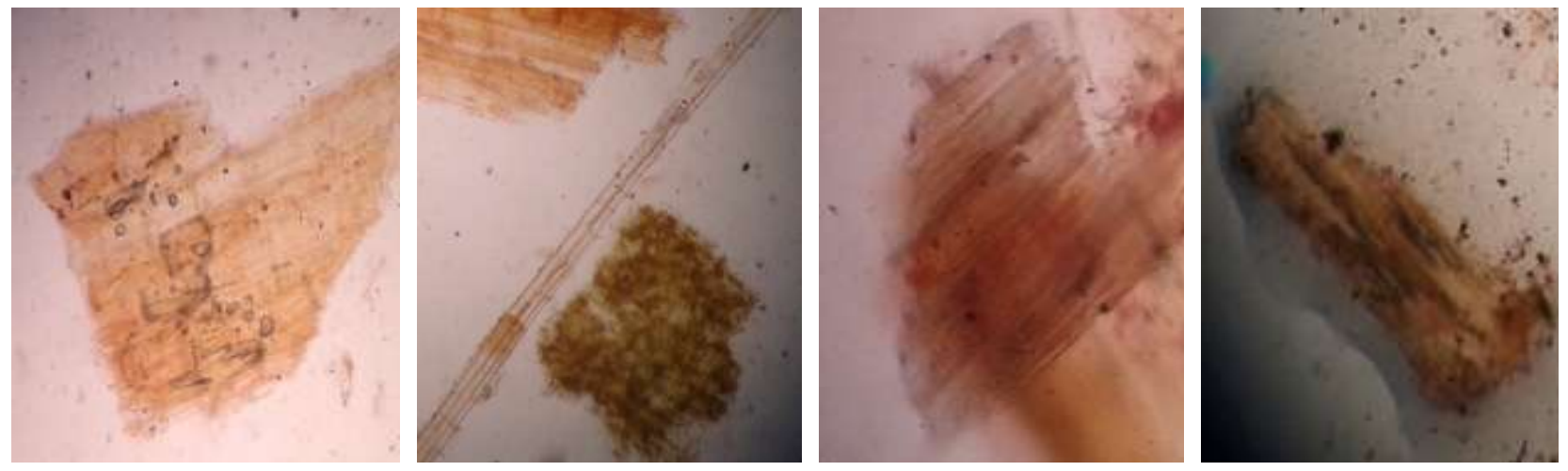

4 5 6 8

Figure 6: Powder microscopyof $\boldsymbol{O}$. basilicum where 1-Stone cell, 2-Lamellar collenchymas, 3-Cork cell, 4-Epidermal cell, 5-Fibers, 6-Medullary rays,7-Wood element

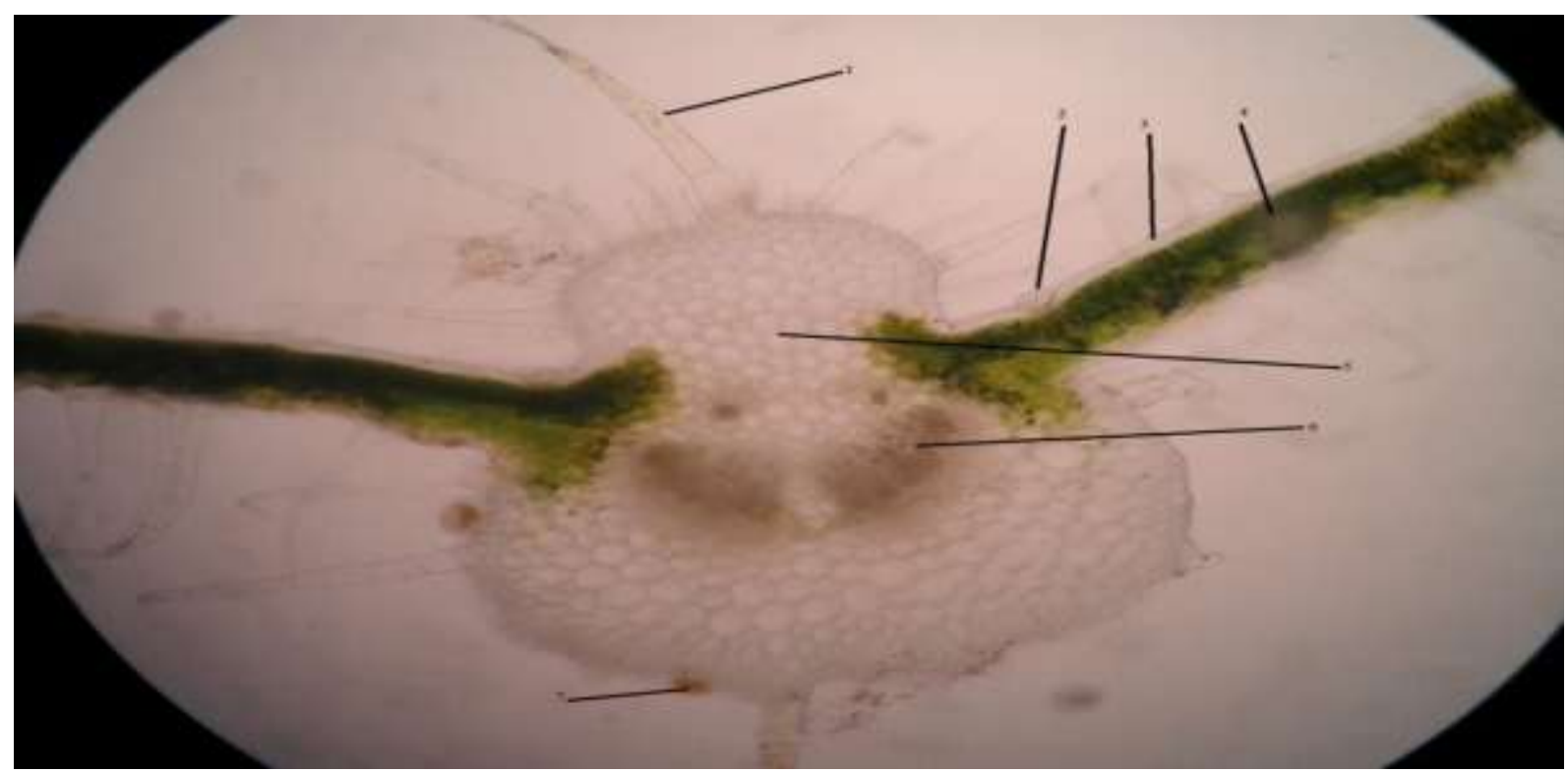

Figure 7: microscopy leaf of 0 . gratissimum where 1-Multicellular covering trichomes, 2Glandular trichomes, 3- Upper epidermis, 4- Upper palsied cell, 5-Collenchymatous cells, 6- Vascular bundle containing xylem \& phloem, 7- oil glands 


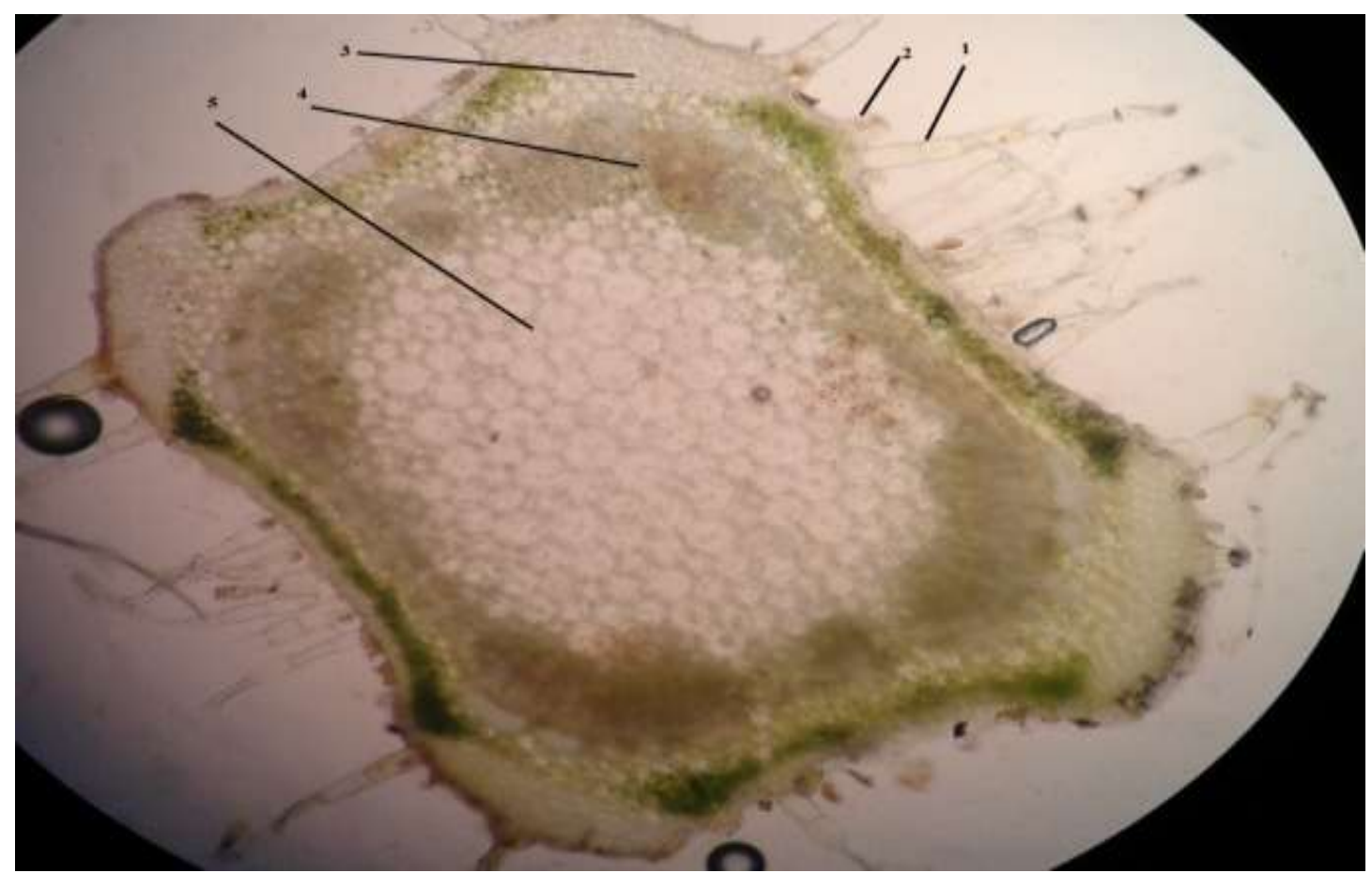

Figure 8:Microscopy stem of $O$. gratissimum Where 1-Multicellular covering trichome, 2Glandular trichome, 3-Collenchymatous cells, 4-Vascular bundle containing xylem \& phloem, 5-Spongy tissue

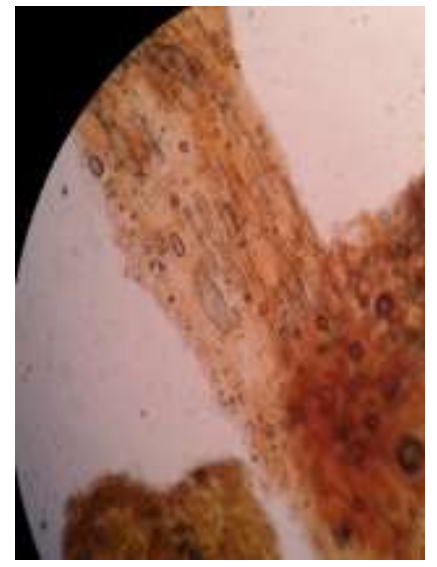

1

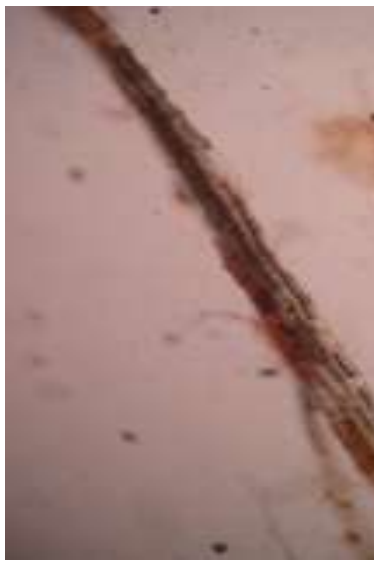

2

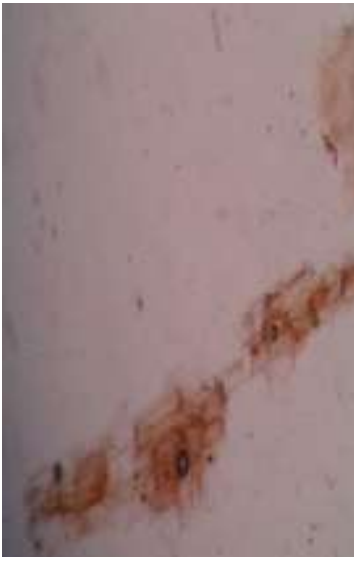

3

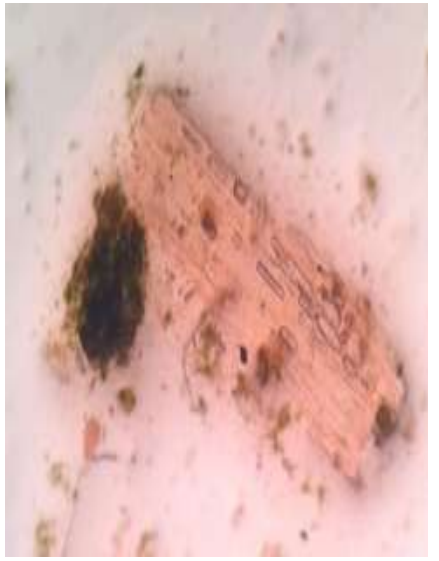

7 


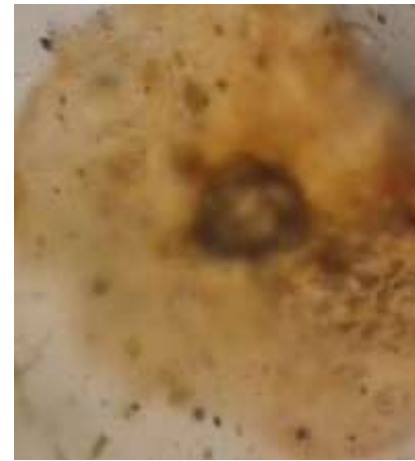

4

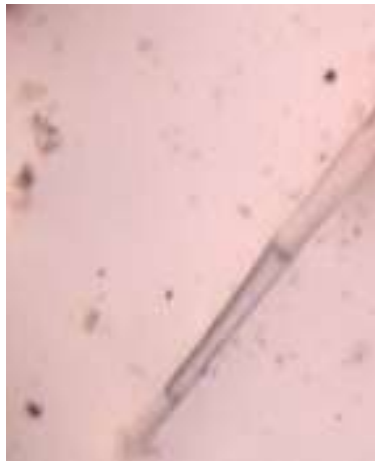

5

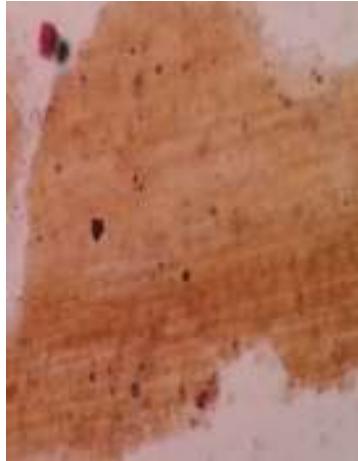

6

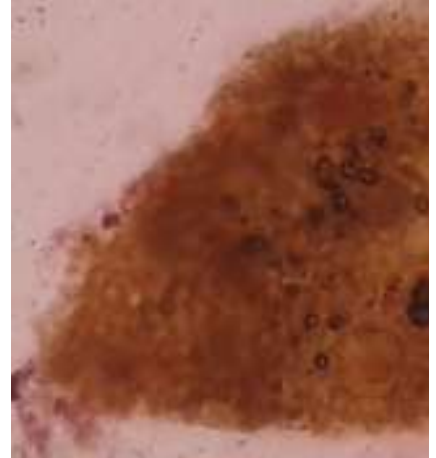

8

Figure 9: Powder microscopy of $O$. gratissimum where 1-Reticulate xylem vessel, 2-Fiber, 3- Cortical cell, 4-Stone cell, 5-Multicelluler trichome, 6-Epidermal cell, 7- Vessels, 8-Oil glands

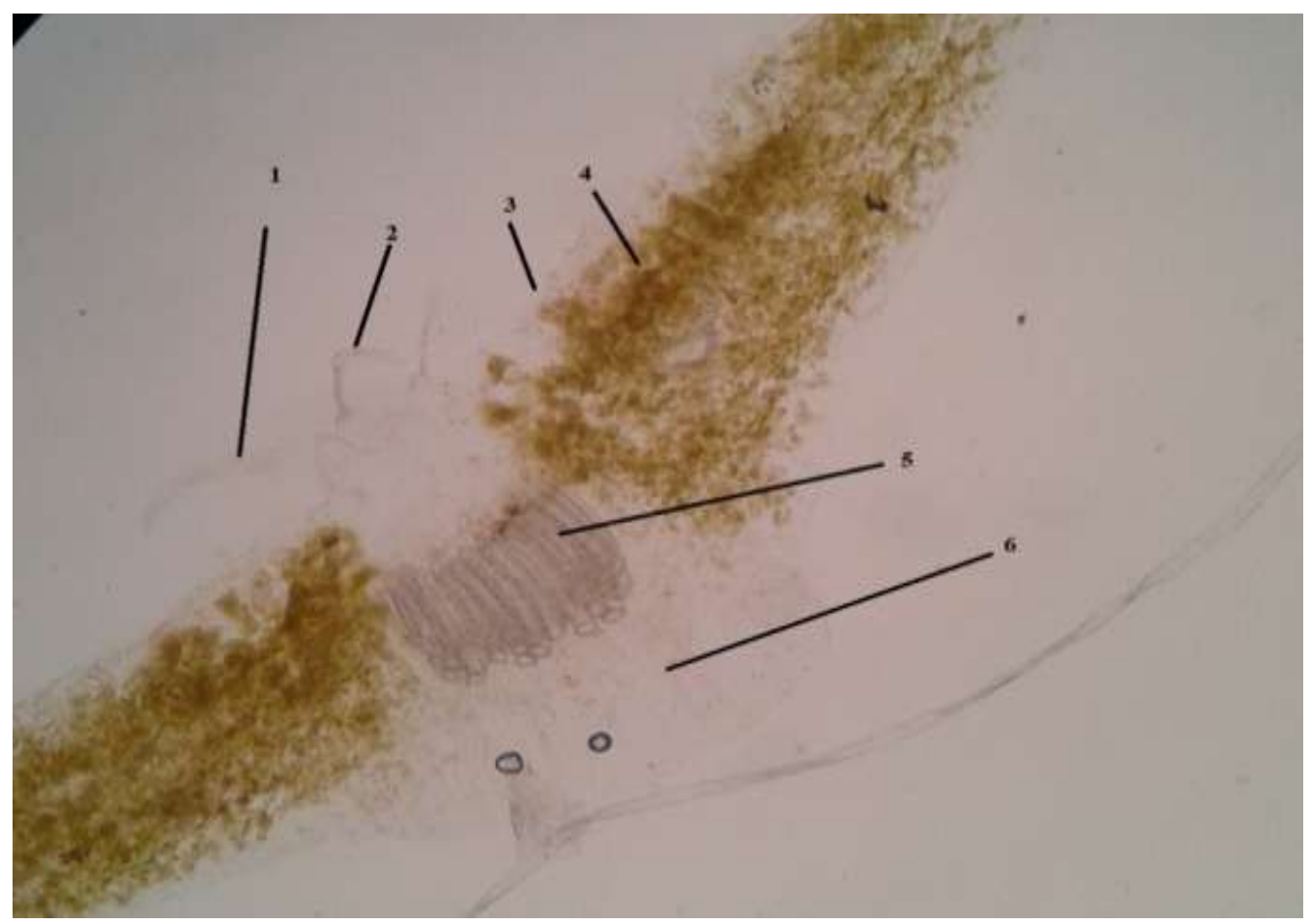




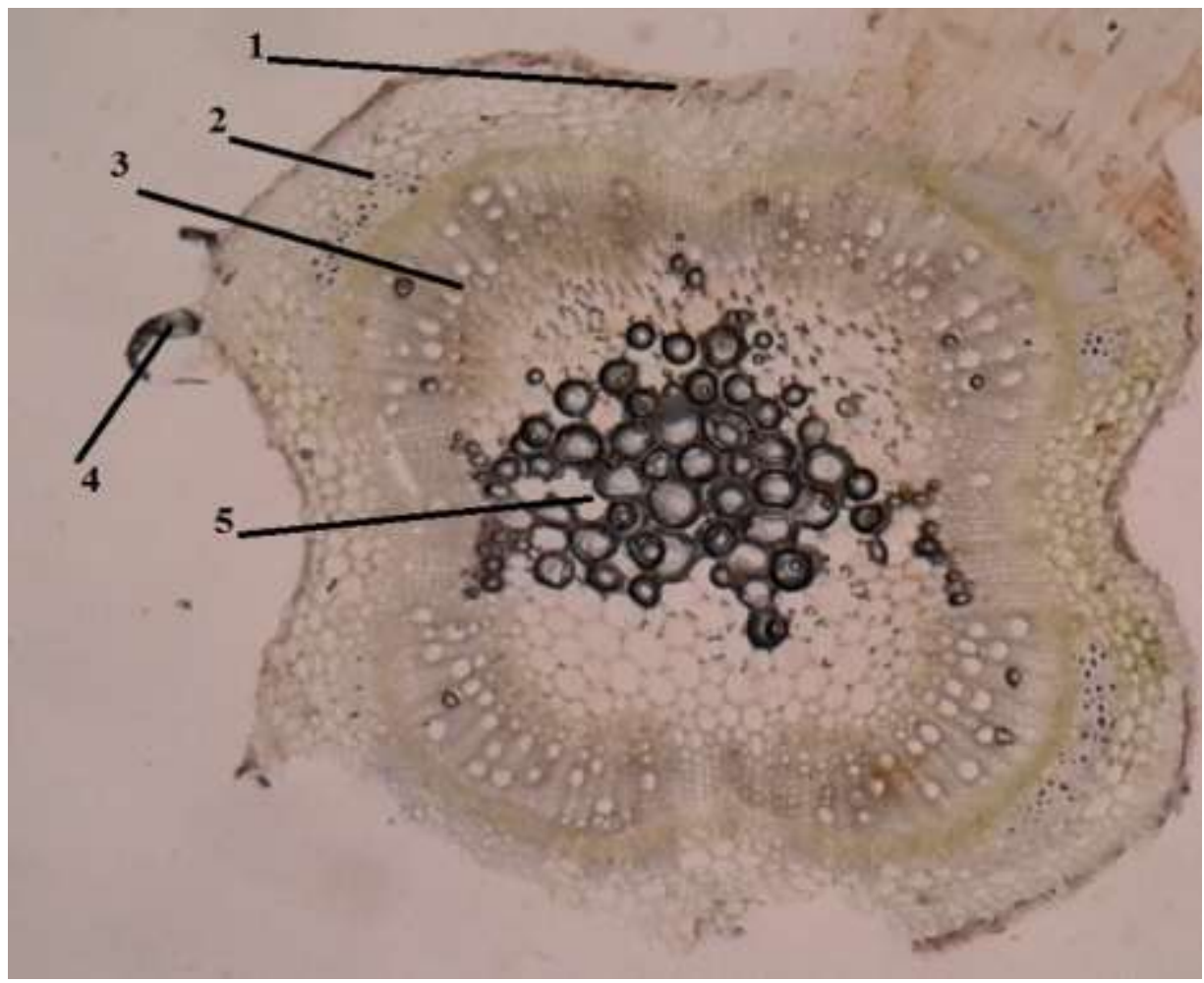

Figure 11: Microscopy of stem of O. kilimandscharicumwhere1-Cork, 2-Collenchymatous cells, 3-Vascular bundle containing xylem \& phloem, 4-Multicelluler curved trichomes, 5Pith

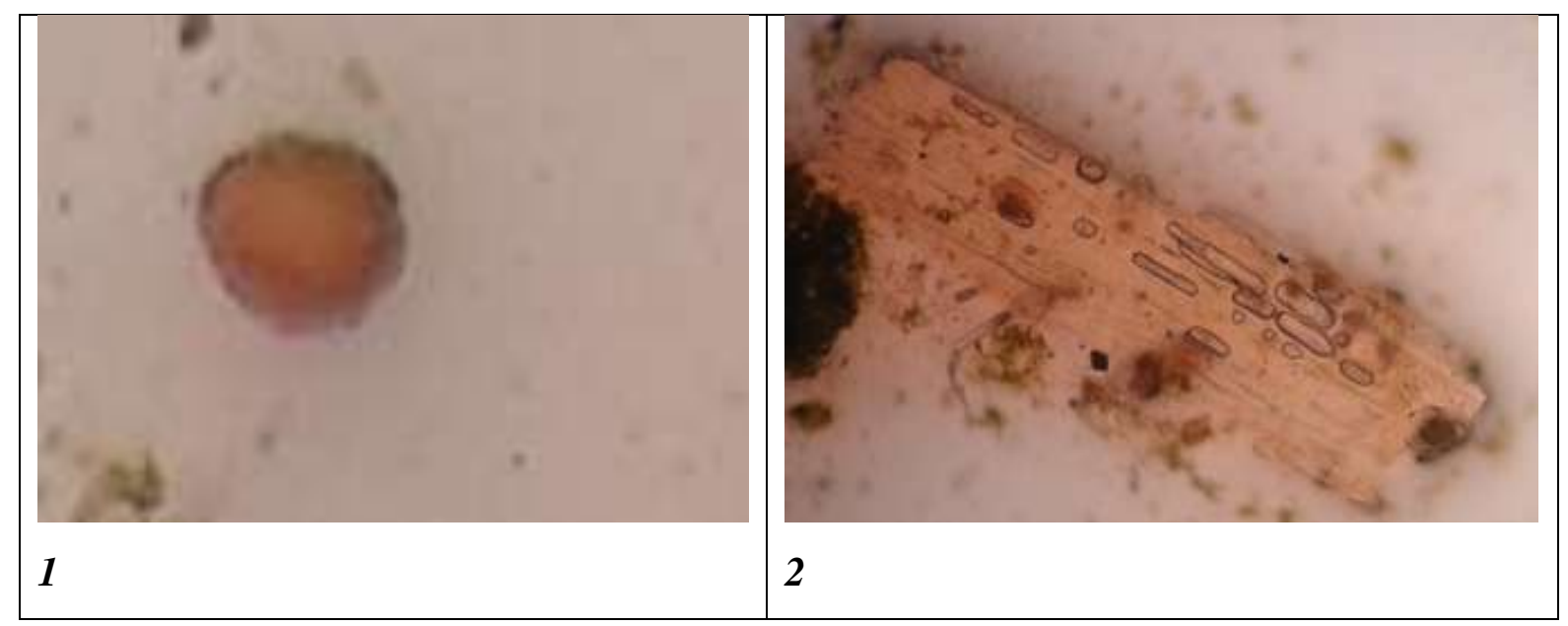




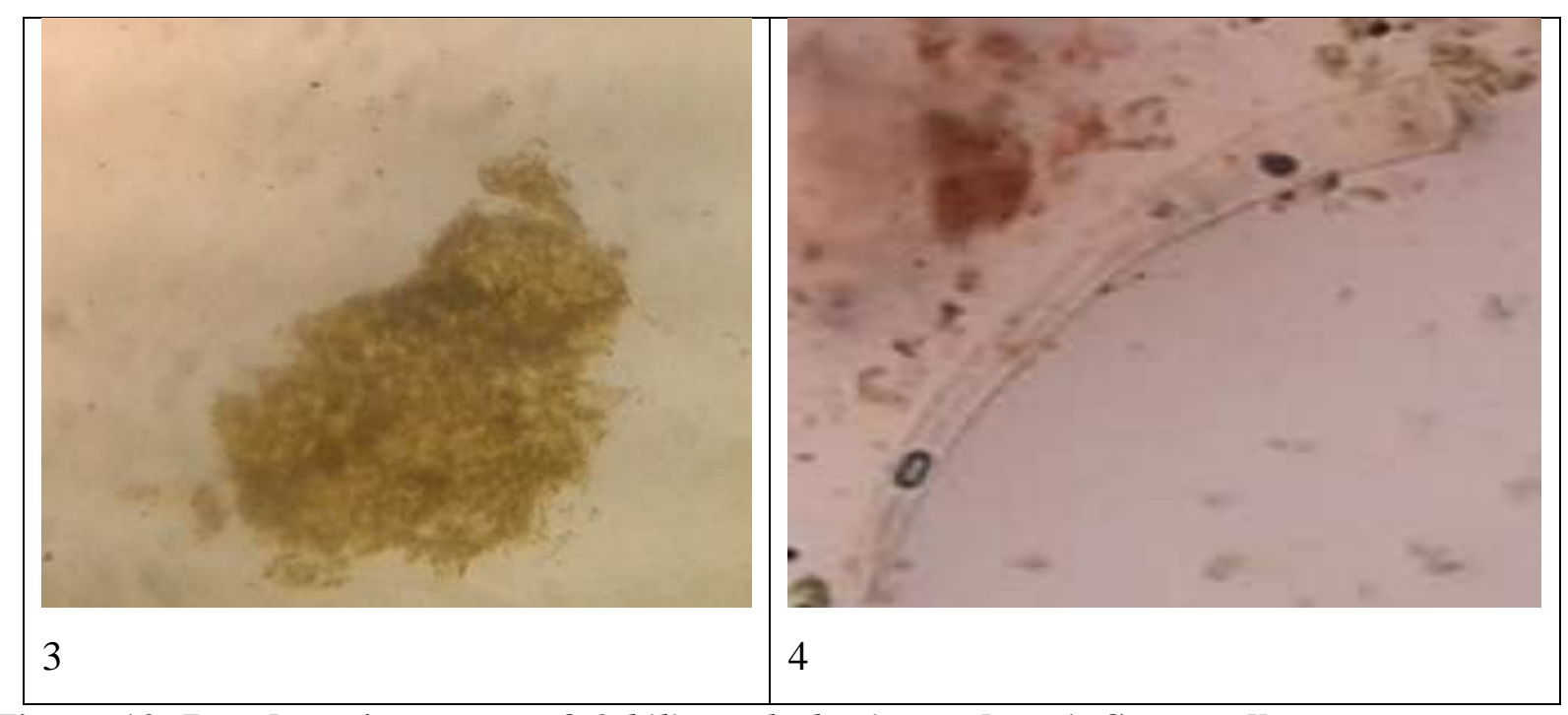

Figure 12: Powder microscopy of O.kilimandscharicumwhere1- Stone cell,

2-Reticulate xylem vessel, 3-multi cellular curved trichomes, 4-Storage parenchyma,

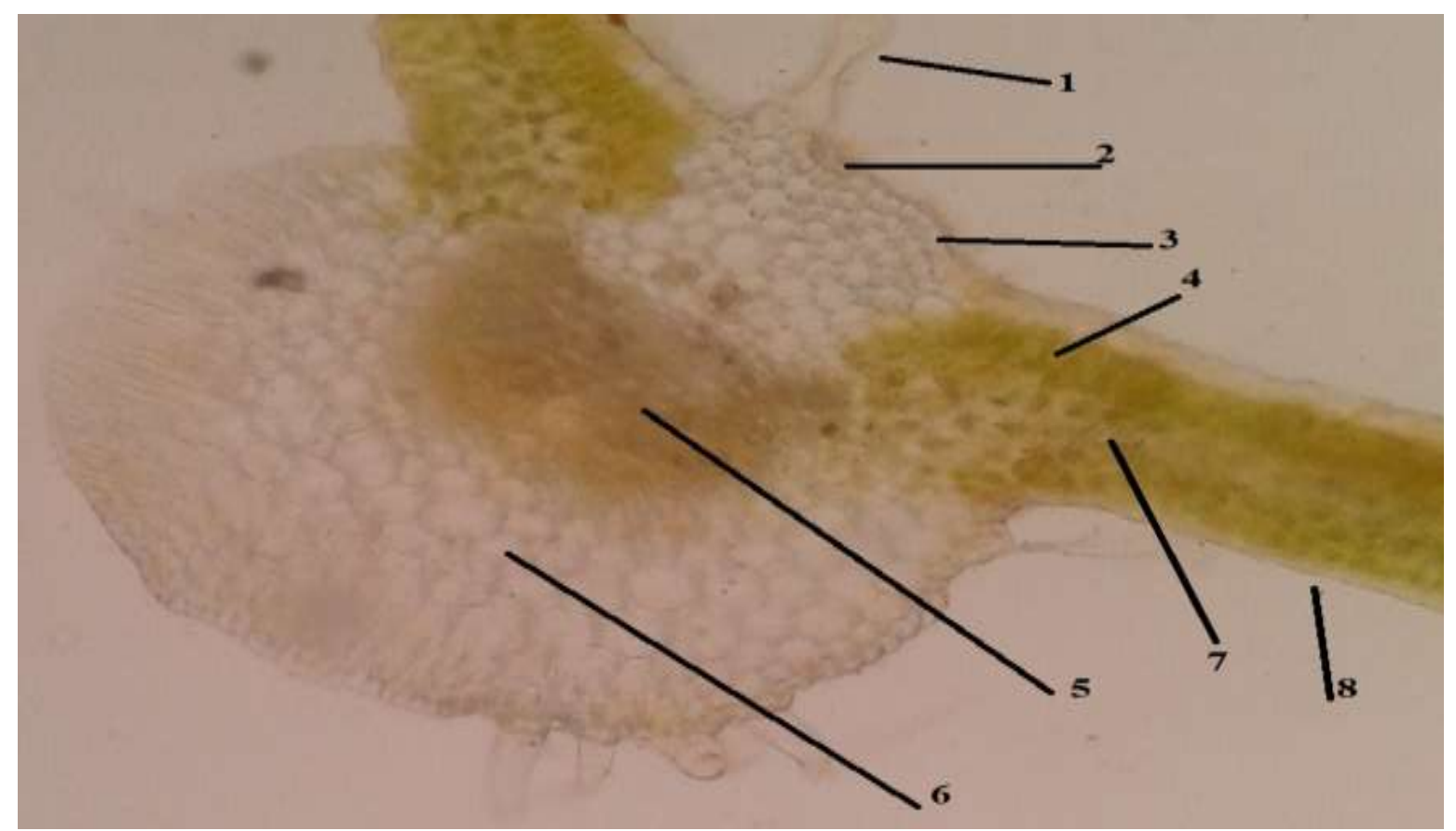




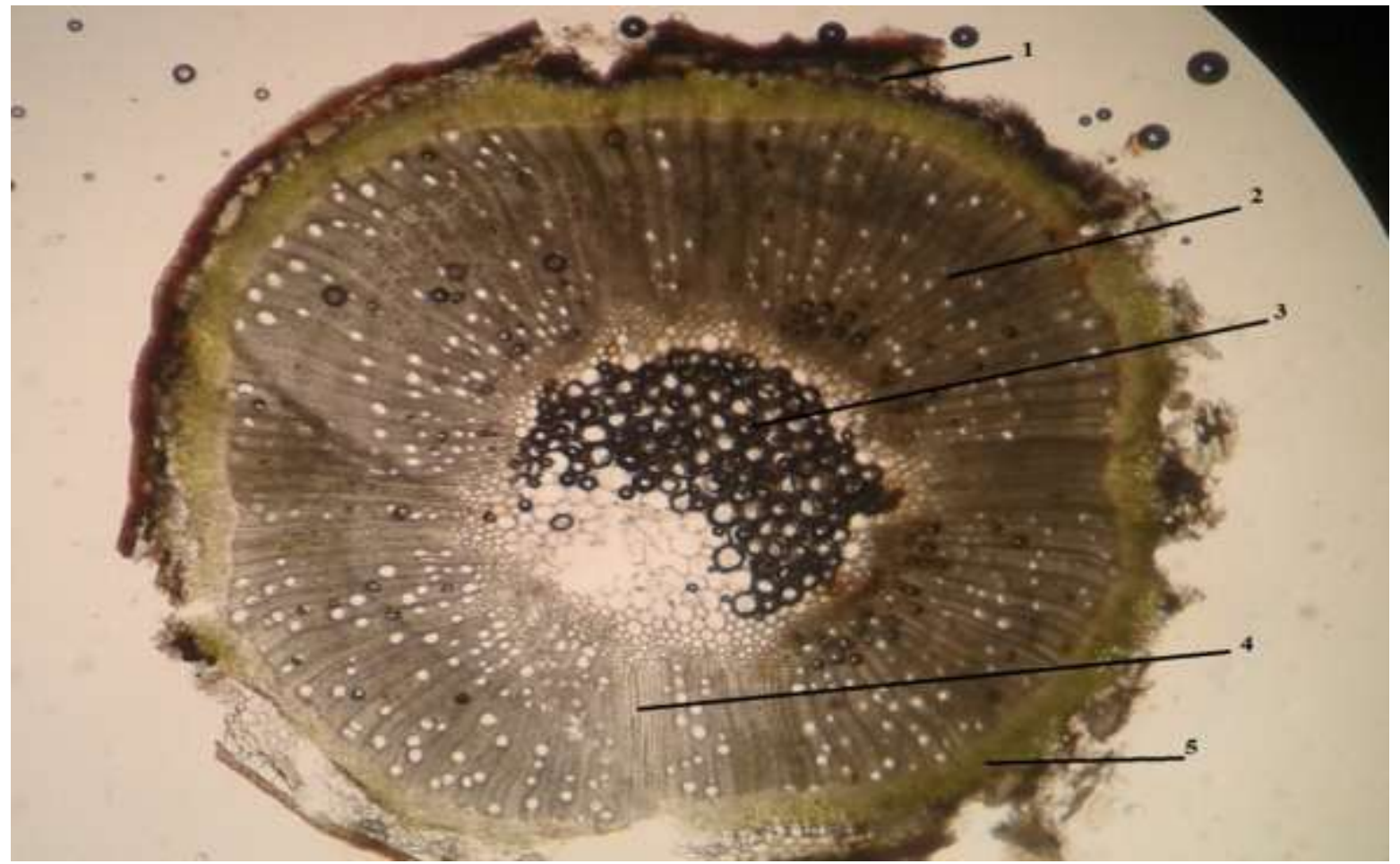

Figure 14: Microscopy stem of O. sanctum 1- Cork, 2- Collenchymatous cells, 3- Pith, 4Medullar rays

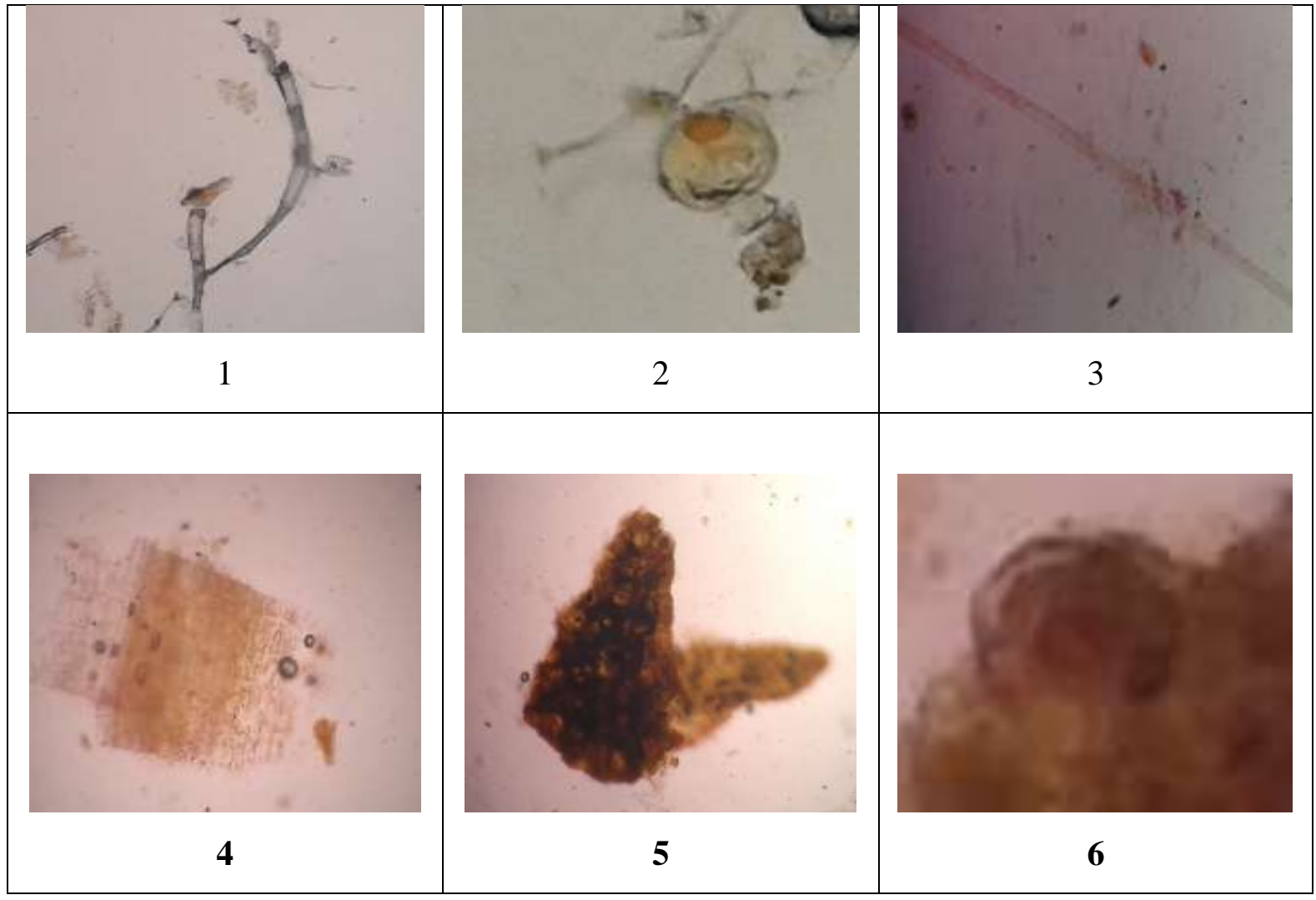

Figure 15: Powder microscopyof $O$. sanctum Where 1- Multicelluler curved trichomes, 
2-Glandular trichomes, 3-Scleranmatous fiber, 4-Epidermal cell, 5-Cork cell 6-Bicuspid stomata

CONCLUSION

As per entitled work "Comparative Pharmacognostical, evaluation of Ocimum species," five species of Ocimum are collected and comparatively evaluated for morphological, microscopical characters. Macroscopy of whole plant, microscopy of leaves and stem as well as powder of whole plant studied in detail. Microscopical examination of leaf and powder drug of $O$. americanum, O.basilicum. gratissimum, O. kilimandscharicum, O.sanctum provided useful information about its correct identity and evaluations. It helps to differentiate species of Ocimum.

\section{REFERENCE:}

1. The Wealth of India,(A Dictionary of Indian Raw material \& Industrial Product) Raw material volume VII:N-Pe [ Council of Scientific \& Industrial Research New Delhi],7989.

2. V. Sharma, A. Joshi, B.K. Dubey, comperative pharmacognostical and phytochemical evaluation (leaf) of different species of ocimum, International Journal of Phytopharmacy , Nov-Dec 2011; 1 (2): 43-49.

3. Pankaj K. Sahu, A. Kumari, Shweta Sao, M. Singh and P. Pandey, Sacred plants and their Ethno-botanical importance in central India: A mini review, International Journal Of Pharmacy \& Life Sciences Explorer Research Article CODEN (USA): IJPLCP, Aug. 2013;4(8)

4. Rajeshwar T, Rao K N V, Sandhya S, David Banji, Murali Krishna P, Sunita CH; Phamacognostic Standerdisation of leaf extract of indogo ferabarberi (ebaceae), herbal Tech Industeries-2011, 10-17.

5. Prasad V. Kadam, Ramesh S. Deoda, Rakesh S. Shivatare, Kavita N. Yadav and Manohar J. Patil, Pharmacognostic, phytochemical and physiochemical studies of Mimusops Elengi Linn stem bark (Sapotaceae), Scholars Research Library, 4 (2):607-613

6. The Wealth of India,(A Dictionary of Indian Raw material \& Industrial Product) Raw material volume VII:N-Pe [ Council of Scientific \& Industrial Research New Delhi],7989.

7. The Wealth of India,(A Dictionary of Indian Raw material \& Industrial Product) First supplement series (Raw material) volume 4-J-Q, National Institute of science, 
Communication and Information Resources CSIR, Dr. K. S. Krishnan Marg, New Delhi 110012, 216-221.

8. Patel D.S., Khare P.K. and Chaurasia B., Identification of Morphologically Close Species of Ocimum L. On The Basis Of Seed Characters, Indian Journal of Plant Sciences, 2015;4 (1), 16-18.

9. http://www.theplantlist.org

10. Abhay Kumar Pandey, Pooja Singh',Nijendra Nath Tripathi, Chemistry and bioactivities of essential oils of some Ocimum species: an overview Asian Pacific Journal of Tropical Biomedicine, September 2014: (4) 682-694.

11. Shadia E, Abd El-Aziz, Elsayed A. Omer and Aly S. Sabra, Chemical Composition of Ocimum americanum Essential Oil and Its Biological Effects Against, Agrotis ipsilon, (Lepidoptera: Noctuidae), Research Journal of Agriculture and Biological Sciences, , 2007 3(6): 740-747.

12. The Wealth of India,(A Dictionary of Indian Raw material \& Industrial Product) First supplement series (Raw material) volume 4-J-Q, National Institute of science, Communication and Information Resources CSIR, Dr. K. S. Krishnan Marg, New Delhi , 216-221.

13. D. Sai Koteswar Sarmaand A. Venkata Suresh Babu, Pharmacognostic and phytochemical studies of Ocimum americanum, Journal of Chemical and Pharmaceutical Research, 2011, 3(3):337-347.

14. Behera Saiprasanna, Babu S Manohar , Ramani Y Roja , Choudhury Prasanta K, Panigrahi Rajeshree, Phytochemical investigation and study on antioxidant properties of ocimum canum hydro-alcoholic leaf extracts, Research article Journal of Drug Delivery \& Therapeutics; 2012, 2(4), 122-128 .

15. Mohsen Taheri Shirazi, Hamid Gholami, Gholamreza Kavoosi, Vahid Rowshan \& Asad Tafsiry, Chemical composition, antioxidant, antimicrobial and cytotoxic activities of Tagetes minuta and Ocimum basilicum essential oils, Food Science \& Nutrition 2014; 2(2): $146-155$.

16. Alia Bilal, Nasreen Jahan, Ajij Ahmed, Saima Naaz Bilal, Shahida Habib, Syeda Hajra, Phytochemical and pharmacological studies on ocimum basilicum linn - a review,IJCRR2012(4 (23)) .73-83 
17. Hemlata Verma, Anil Pratap Singh, Neeraj verma, Arpita Singh, Manmohan Singh, Pharmacognostic, preliminary phytochemical and tlc finger print profile investigation on ocimum gratissimum, Deccan Pharma Journal: 2010,1(4):55-66.

18. Bagora Bayala, Imaël HN Bassole, Riccardo Scifo, Charlemagne Gnoula1,8, Laurent Morel, Jean-Marc A Lobaccaro, Jacques Simpore. Anticancer activity of essential oils and their chemical components - a review, Am J Cancer Res 2014; 4(6):591-607.

19. Lexa G. Matasyoha,, Josphat C. Matasyoh b, Francis N. Wachira c, Miriam G. Kinyua d, Anne W. Thairu Muigai a and Titus K. Mukiama ,Antimicrobial activity of essential oils of ocimum gratissimum 1. from different populations of kenyaResearch Paper Afr. J. Traditional, Complementary and Alternative Medicines;(2008) 5 (2): 187 - 193

20. Gill Dolly, Soni Nidhi , Sagar Bps , Raheja Shweta , Agrawal Shikha ,Ocimum kilimandscharicum : a systematic review Journal of Drug Delivery \& Therapeutics; 2012, 2(3): 45-52 .

21. Varinder Singh, Pawan Krishan, and Richa Shri, Ocimum kilimand scharicum Guerke: Phytochemical and Pharmacological Aspects: A Review, 2014(2 (3)) ,2-11.

22. Shahedur Rahman, rezuanual Islam, M. Kamuzzaman, Khasrual Alam and Abu Hena Mastofa Jamal, Ocimum sanctum L: A review of phytochemical and pharmacological profile. American journal of drug discovery and Development, 2011; 4(7): 95-105.

23. R. K. Joshi \& S. L. Hoti, Chemical composition of the essential oil of Ocimum tenuiflorum L. (Krishna Tulsi) from North West Karnataka, India, Plant Science Today (2014) 1(3): 99-102.

24. Behera Saiprasanna, Babu S Manohar , Ramani Y Roja , Choudhury Prasanta K, Panigrahi Rajeshree, Phytochemical investigation and study on antioxidant properties of ocimum canum hydro-alcoholic leaf extracts, Research article Journal of Drug Delivery \& Therapeutics; 2012, 2(4), 122-128 .

25. Valtcho D. Zheljazk, Charles L. Cantrell, William B. Evans M. Wayne Ebelhar, Christine Coker, Yield and Composition of Ocimum basilicum L. and Ocimum sanctum L. Grown at Four Locations, HORTSCIENCE 2008;43(3):737-741.

26. Saira Khaliq, Zafar Ullah Zafar, Habib ur Rehman Athar, Rehana Khaliq, Physiological and biochemical basis of salt tolerance in Ocimum basilicum L., Journal of Medicinal Plants Studies Year, 2014, (2( 1)); 18-27. 
27. Dinanath D Patil, Dnyandeo K. Mhaske, Gurumeet C. Wadhawa, Antibacterial and Antioxidant study of Ocimum basilicum Labiatae (sweet basil),Journal of Advanced Pharmacy Education \& Research2011,(2): 104-112 .

28. K.S. Prabhu, R. Lobo, A.A. Shirwaikar and A. Shirwaikar, Ocimum gratissimum: A Review of its Chemical, Pharmacological and Ethnomedicinal Properties, The Open Complementary Medicine Journal, 2009, (1); 1-15.

29. http://www.agriculturalproductsindia.com

30. Gill Dolly, Soni Nidhi, Sagar Bps , Raheja Shweta , Agrawal Shikha, Ocimum kilimandscharicum : a systematic review Journal of Drug Delivery \& Therapeutics; 2012, 2(3): $45-52$

31. Smitha G. R., Thania Sara Varghese ,P. Manivel, Cultivation of Ocimum, Icar directorate of medicinal and aromatic plants research boriavi, anand - 387 310, Gujarat. ;10-30

32. Anand Shukla, Kawaljeet Kaur, Puneet Ahuja, Tulsi the Medicinal Value, Online International Interdisciplinary Research Journal, 2013(3(2)); 9-14.

33. Kirtikar KR, Basu BD. Indian Medicinal Plants with Illustrations. 2nd edition. Uttaranchal: Oriental Enterprises; 2003.(8) 2701-2705

34. The Ayurvedic Pharmacopoeia Of India Part - II (Formulations) volume - II first edition, Government of India Ministry of Health and Family Welfare Department of Ayurveda, Yoga \& Naturopathy, Unani, Siddha and Homoeopathy, Hew Delhi 2008 (pg- 170 -176)

35. Sapna Phadtare, Rahul Pandit, Vaibhav Shinde, Kakasaheb Mahadik, Comparative Phytochemical and Pharmacological Evaluations of Two Varieties of Ocimum basilicum for Antiarthritic Activity, Journal of Pharmacognosy and Phytochemistry2013; (2(2)), 158-167.

36. Shafqatullah, Muhammad Khurram, Asadullah, Khaliqurrehman and Farhat Ali Khan, Comparative Analyses of Ocimumsantum Stem and Leaves for Phytochemicals and Inorganic Constituents Middle-East Journal of Scientific Research 2013; (2): 236-240.

37. S. RaseethaVani, S.F. Cheng and C.H. Chuah, Comparative Study of Volatile Compounds from Genus Ocimum, American Journal of Applied Sciences 2009; 6 (3): 523-528.

38. Maria Loredana Soran, SimonaCodruta Cobzac, Codruta Varodi, Ildiko Lung, Emanoil Surducan and Vasile Surducan, The extraction and chromatographic determination of the 
essentials oils from Ocimum basilicum L. by different techniques, Journal of Physics: Conference 2009;(1), 1-6.

39. Raman Chawla, Pallavi Thakur, AyushChowdhry, SaritaJaiswal, Anamika Sharma, Rajeev Goel, Jyoti Sharma, SmrutiSagarPriyadarshi, Vinod Kumar, Rakesh Kumar Sharma and Rajesh Arora, Evidence based herbal drug approach in coping with challenges of holistic management of diabetes: a dreadful lifestyle disorder of $21 \mathrm{st}$ century Journal of Diabetes \& Metabolic Disorders 2013; (12):2-35.

40. SantanuKarMahapatra, Subhankari Prasad Chakraborty, and Somenath Roy, Immunomodulatory Role of Ocimum gratissimum and Ascorbic Acid against NicotineInduced Murine Peritoneal Mlular Longevity 2011:1-11.

41. Etinosa O. Igbinosa, Edwina O. Uzunuigbe, Isoken H. Igbinosa, Emmanuel E. Odjadjare, Nicholas O. Igiehon, Oke A. Emuedo, In vitro assessment of antioxidant, phytochemical and nutritionalproperties of extracts from the leaves of Ocimum gratissimum(linn) Afr $\mathbf{J}$ Tradit Complement Altern Med. 2013,10(5): 292-298.

42. Varinder Singh, PawanKrishan, and RichaShri, Ocimum Kilimandscharicum Guerke: Phytochemical and Pharmacological Aspects: A Review,research and reviews: journal of pharmacognosy and phytochemistry.2014 2(3) : 95-105.

43. FofieN'guessan Bra Yvette, Coulibaly Kiyinlma, Kone-BambaDiénéba, Phamacognostic study of Ocimum gratissimum Linn. : Pharmafood plant. Journal of Pharmacognosy and Phytochemistry 2014; 2 (5): 74-79.

44. S. Khair-ul-Bariyah, D. Ahmed and M. Ikram, Ocimum Basilicum: A Review on Phytochemical and Pharmacological Studies Pak. J. Chem.2012, 2(2):78-85.

45. K. M. Mominul Islam and Hisashi Kato-Noguchi, Phytotoxic Activity of Ocimum tenuiflorum Extracts on Germination and Seedling Growth of Different Plant Species, Scientific World Journal. 2014; 2(1):8.

46. K Reshma, A V R, M Dines and D M Vasudevan, Radioprotectiveeffects of Ocimum flavonoids on leukocyte oxidants and antioxidants in oral cancer Indian Journal of Clinical Biochemistry 2008,23 (2) 171-175.

47. Choudhury Golak Bihari, Behera Manaswini, Jena Prabhat Kumar and Tripathy Sujit Kumar, Pharmacognostical and phytochemical investigation of various tulsiplants available in south eastern odisha, International Journal of Research in Pharmaceutical and Biomedical Sciences 2011:2 (2) 60-63. 
48. S.L. Deore, S.S. Khadabadi, B.A. Baviskar, Pharmacognosy and Phytochemistry, A comprehensive Approach, 2014:101-103.

49. Khandelwal K R, edited by Vrunda K Sethi; Practical Pharmacognocy, $20^{\text {th }}$ edition 2010, Nirali prakashan Pune.

50. Rajeshwar T, Rao K N V, Sandhya S, David Banji, Murali Krishna P, Sunita CH; Phamacognostic Standerdisation of leaf extract of indogo ferabarberi (ebaceae), herbal Tech Industeries-2011, 10-17.

51. Prasad V. Kadam, Ramesh S. Deoda, Rakesh S. Shivatare, Kavita N. Yadav and Manohar J. Patil, Pharmacognostic, phytochemical and physiochemical studies of Mimusops Elengi Linn stem bark (Sapotaceae), Scholars Research Library, 4 (2):607-613

52. S.S. Khadabadi, S.L. Deore, B.A. Baviskar, textbook of Pharmacognosy, first edition, Pharmamed press publication, 422-424 